\title{
Firm Life Cycle and the Value Relevance of Intangible Assets: The Impact of FRS 138 Adoption
}

\author{
Hartini Jaafar and Hazianti Abdul Halim
}

\begin{abstract}
This study examines the relationship between accounting choice for intangible assets and their value relevance as well as the moderating effect of firm life cycle on this relationship before and after the adoption of FRS 138 Intangible Assets in accordance with the International Financial Reporting Standards (IFRS) in 2006 in Malaysia. The sample used in this study consists of 2,042 and 2,289 firm-years for the pre-and post-IFRS period, respectively which are classified into three life cycle stages; Growth, Mature and Decline. The findings indicate that during the pre-IFRS period, capitalized identifiable intangible assets are regarded by the Malaysian market as value relevant. The results also suggest that although there is a significant difference in value relevance between Growth and Mature firms, the same effect is not present between Mature and Decline firms. A comparison between the pre- and post-IFRS period suggests that the market attaches higher value relevance to identifiable intangible assets after the adoption of IFRS. The findings also show that there is no significant difference with regards to the impact of the adoption of FRS 138 among all three firm life cycle stages.
\end{abstract}

Index Terms-FRS138, value relevance, firm life cycle.

\section{INTRODUCTION}

Consistent with the Malaysian Accounting Standards Board's (MASB) commitment to its convergence policy with IFRS as a basis for the financial reporting system in Malaysia, the Financial Reporting Standards (FRS) were issued to replace MASB Standards (MASB) in 2004. The implementation of FRS for intangible assets in 2006 (FRS 138 Intangible Assets) resulted in a major change in Malaysian accounting practices for these assets. This is because in the pre-IFRS period, there was no specific standard for intangible assets and further, Malaysia did not adopt the International Accounting Standards (IAS) 38 Intangible Assets although it was issued by the International Accounting Standards Board (IASB) in 1998. With no single standard in place for intangible assets, there was some leeway for managers in accounting for these assets. However, with the adoption of IFRS, this discretion has been largely restricted. Conflicting arguments have been presented concerning this substantial discretion and its impact on the value relevance of intangible assets [1]-[4]. From one point of view, it can be argued that managers could use this discretion to convey accurately their private information to the market, thereby reducing the information asymmetry

Manuscript received June 6, 2013; revised August 6, 2013.

Hartini Jaafar and Hazianti Abdul Halim are with the Department of Accounting and Finance, Faculty of Management and Economics, Universiti Pendidikan Sultan Idris, 35900 Tanjong Malim, Perak, Malaysia (e-mail: hartini@fpe.upsi.edu.my, hazianti@fpe.upsi.edu.my). between managers and investors. Alternatively, the largely unregulated setting can be viewed as promoting managerial opportunistic behaviour that could lead to the manipulation of accounting numbers. Therefore, this has raised concerns over the impact of the more restrictive accounting practice for intangible assets in the post-IFRS period on value relevance. As such, the debate on whether allowing greater flexibility to managers in accounting for intangible assets enhances or adversely affects the quality of accounting information in financial reporting is likely to continue.

The general objective of this study is to examine empirically the relationships among firm life cycle, accounting choice for intangible assets and the value relevance of these assets in the period before and after the adoption of IFRS. More specifically, in the context of intangible assets, this study seeks to understand and examine the effect of accounting choice on their value relevance and also the role of firm life cycle in the relationship between accounting choice and value relevance during the pre-IFRS period. Further, this study aims to investigate the impact of the change in regulatory accounting practices on the relationship between first, accounting choice and value relevance and second, firm life cycle, accounting choice and value relevance.

\section{LITERATURE REVIEW AND HYPOTHESES DEVELOPMENT}

\section{A. Accounting for Intangible Assets in Malaysia}

The history of accounting standards setting in Malaysia can be described as complex, primarily due to the existence of two accounting bodies that controlled the accounting regulation since the 1970s until early 1997 . These were the Malaysian Institute of Accountants (MIA) and the Malaysian Institute of Certified Public Accountants (MICPA), which was previously known as the Malaysian Association of Certified Public Accountants (MACPA). Interestingly, the implementation of existing accounting standards at that time were not mandatory for listed firms. Accounting standards pertaining to intangible assets during that time include the Malaysian Accounting Standard (MAS) 6 Accounting for Goodwill which was issued by MIA and the International Accounting Standard (IAS) 9 Research and Development Costs, which was issued by the IASB (previously known as the International Accounting Standards Committee (IASC)). MAS 6 and IAS 9 standards were both applicable for implementation until 1997 among the MIA members only, while MICPA members were required to adopt and apply IAS 9 in their own individual practice. The MASB was established under the Financial Reporting Act (1997) in 1997 
as an independent authority to develop and issue accounting and financial reporting standards. Despite the issuance of IAS 38 in 1998 by the IASB to guide accounting for intangible assets in countries adopting the IASB standards, this particular standard was not adopted and implemented in Malaysia. Standards on intangible assets applicable in Malaysia prior to adoption of FRS 138 in 2006 include MASB 21 Business Combinations and MASB 4 Research and Development Costs.

The required implementation of IFRS by countries in the European Union and most Asia-Pacific countries is intended to increase the comparability of accounting standards and regulations and to enhance the quality and usefulness of financial statements. In a move towards the adoption of IFRS, FRS 138 was implemented in Malaysia in 2006. This standard applies to annual reporting periods beginning on or after 1 January 2006. It mirrors the requirements in IAS 38 with regards to the recognition and measurement of purchased goodwill, identifiable intangible assets and internally generated goodwill and intangible assets.

\section{B. Accounting for Intangible Assets, Value Relevance and Firm Life Cycle}

Numerous studies have been conducted in different accounting regulatory settings that examine the impact of IFRS on accounting information quality. These studies generally examine the effect of the change on accounting information value relevance and report mixed findings. For example, studies conducted in Greece [5], [6] and France [7] provide evidence that IFRS adoption leads to higher quality of financial statements as reflected in the more value relevant accounting measures. Reference [8], on the other hand, finds no support to conclude that financial statements prepared under IFRS in the U.K., Hong Kong and Singapore are incrementally value relevant to financial statements prepared under GAAP, while [9] report improved value relevance for book value but not earnings in Malaysia.

Nonetheless, limited studies have been conducted to examine the effect of IFRS in the context of the value relevance of intangible assets. Reference [10] for example, investigates whether and to what extent the implementation of IFRS affects the value relevance of intangible assets using a sample of Italian publicly listed firms. Using the [11] model, they examine both the incremental and relative value relevance of intangible assets following the mandatory adoption of IFRS. The findings show that goodwill and identifiable intangible assets are value relevant under both Italian GAAP and IFRS. However, Italian firms experienced a statistically significant decrease in the value relevance of intangible assets, particularly goodwill, after the introduction of the new accounting standard. They argue that IFRS recognition criteria that require the impairment test of goodwill and the subsequent higher discretion in goodwill valuation may provide investors with less useful information. This is because the Italian reporting environment can be characterised by a weak corporate governance system and low financial transparency, leading to potentially opportunistic behaviour by managers.

Using a sample of all non-finance firms listed on the main market of the Portuguese Stock Exchange, [12] find that goodwill and the aggregate amount of identifiable intangible assets reported under the Portuguese GAAP are value relevant. However, when considering the subclasses of identifiable intangible assets, the amounts recognised for intellectual property and R\&D expenditures do not appear to be value relevant. The findings also suggest that, while the adoption of IFRS had no impact on the value relevance of identifiable intangible assets as a whole, it has a positive effect on the value relevance of goodwill. Further, when the subclasses of identifiable intangible assets are analysed, evidence of an increase in the value relevance is found for other identifiable intangible assets (such as start-up costs, intangible assets in development and prepayments for purchases of identifiable intangible assets) and capitalised R\&D costs. They argue that the change in the accounting system potentially reduce earnings manipulation practices due to more restrictive requirements, thus leading to the recognised amounts of these expenditures being regarded by the investors as having future economic benefits. Meanwhile, [13] examine the effect of IFRS adoption on the value relevance of intangible assets in Australia. Based on a sample of 599 ASX firms listed in 2006, they compare the Australian GAAP and IFRS balances for goodwill and identifiable intangible assets reported in the annual reports. The results provide partial support for IFRS-measured goodwill being incrementally value relevant but no support that IFRS measures of identifiable intangible assets reflect value-relevant information incremental to that conveyed under Australian GAAP. Further, they also find strong support for the claim that identifiable intangible assets measured under Australian GAAP provide value-relevant information to investors beyond IFRS but weak support that goodwill reported under Australian GAAP is incrementally more value relevant than IFRS. Taken together, studies discussed in this section provide mixed support for the value relevance of accounting choice for intangible assets. While some studies suggest that a less conservative accounting method choice that allowed intangible assets to be recognised as assets rather than expensed when incurred has the potential to provide more relevant information to investors, there are also studies that provide no support for this proposition. Nonetheless, the overall results indicate that the disclosure of non-financial information that captures the notion of intangible assets results in improved information usefulness. Further, the introduction of the new accounting regime (IFRS) is found to have an impact on the value relevance of intangible assets and that this impact varies depending on the accounting regulatory environment.

Nonetheless, the conclusions drawn by some of the studies that the discretion is not being used opportunistically by the management or that the capitalisation of intangible assets is used to signal firm quality when the information is found to be value relevant could be flawed. This is because the effect of firm-specific characteristics on accounting choice is not controlled for in most of the studies. References [14], [15], for instance, note that one rationale for accounting choices is information signalling, particularly when managers have a competitive advantage in providing information about the firm's future cash flows. These choices are unlikely to be used by firms randomly, suggesting that there are certain 
firm-specific characteristics that will determine this choice. The value of a firm can be represented by its present value of assets-in-place as a result of past investments and the present value of future profitable investments or growth opportunities [16], [17]. The value of assets-in-place relative to the value of growth opportunities changes as a firm develops through its life cycle and is expected to differ in each of the life cycle stages [18]. For example, when a firm is first set up, its value consists almost exclusively of ideas the founders or owners have for profitable future investments, which are in the form of growth opportunities, rather than its assets-in-place [17]. However, as the firm matures, its growth opportunities are financed and converted into assets (and liabilities) and the fraction of value attributable to its assets-in-place increases relative to that of its growth opportunities. Based on [17]' framework, [18] proposes that, at a given time, a firm's value relevant attributes consist of the following six factors:

- Liquidation value of assets-in-place;

- Amount of future cash flows from assets-in-place;

- Risk of future cash flows from assets-in-place;

- Amount of future cash flows from growth opportunities;

- Risk of future cash flows from growth opportunities;

- Value of the option to invest in growth opportunities.

Throughout the firm life cycle, although firms are required to report the same information, differential value relevance of accounting information occurs because the set of value relevant attributes about future cash flows for the two components of assets-in-place and growth opportunities is different in each life cycle stage [18]. Furthermore, assuming market efficiency with respect to public information, the information conveyed by accounting numbers about these attributes can change over the firm life cycle. In order to be value relevant, accounting numbers must provide information about at least one of the six factors. If the relative importance investors place on each of these six factors differs in different stages of the life cycle of the firm, then the value relevance provided by accounting numbers is also likely to be different. This suggests that a firm, at different stages of its life cycle, can be valued differently depending on the relative proportion of its assets-in-place and growth opportunities. Assets-in-place are generally tangible assets such as property, plant and equipment (PPE) and financial assets whose value to the firm can be approximated by market values independent of the firm's strategy [19], [3]. Growth opportunities, on the other hand, are real options that a firm has or may create to make future investments that earn a rate of return in excess of its opportunity cost of capital [17]. Thus, a distinguishing feature of growth opportunities is that their value depends on future managerial discretion which, in turn, is contingent on the evolving market and/or technological conditions [20], [3]. This indicates that assets-in-place and growth opportunities can be viewed as tangible and intangible assets, respectively. Viewing [17] distinction between assets-in-place and growth opportunities as tangible and intangible assets, respectively, is also consistent with [3], [19]. This suggests that intangible assets, in general, contribute to a firm's value creation as they give rise to growth opportunities [3], [17], [21], [22]. Exploitation of these growth opportunities requires investments and whether such investments will be made depends on the result of initial investments to develop intangible assets. Thus, intangible assets represent an option to pursue growth or to abandon such opportunities.

In summary, the facts that: 1) firm value at a particular time is represented by assets-in-place and growth opportunities; 2) the proportion of assets-in-place and growth opportunities varies in accordance with firm life cycle stages; and 3) firm life cycle can be linked to intangible assets through growth opportunities, have two important implications. First, because the proportion of these two firm value components differs in each life cycle stage, the value relevance of intangible asset information will be different depending on the firm's position in its life cycle stages. Second, due to the varying proportion of firm value components, firms in different stages of their life cycle will have different needs with regard to accounting choice for intangible assets, especially in signalling firm value and reducing information asymmetry. This implies that the effect of accounting choice for intangible assets on the value relevance of these assets is potentially moderated by firm life cycle stages. The above discussion leads to the following hypotheses tested in this study:

- H1: Intangible assets capitalised during the pre-IFRS period are value relevant

- H2a: Growth firms that choose to capitalise intangible assets during the pre-IFRS period have higher value relevance of intangible assets than mature firms.

- H2b: Decline firms that choose to capitalise intangible assets during the pre-IFRS period have lower value relevance of intangible assets than mature firms.

- H3: The value relevance of intangible assets for firms that choose to capitalise intangible assets is higher during the pre-IFRS than the post-IFRS period.

- H4a: The effect of the change in the value relevance of intangible assets between the pre- and post-IFRS periods is higher for growth firms than mature firms.

- H4b: The effect of the change in the value relevance of intangible assets between the pre- and post-IFRS periods is lower for decline firms than mature firms.

\section{RESEARCH METHODOLOGY}

\section{Firm Life Cycle Classification Methodology}

The nature of this study that requires a focus on the financial reporting practices of Bursa Malaysia public-listed firms suggests that the main selection criterion for a life cycle classification methodology is its ability to support a large sample size. Furthermore, because this study is interested in addressing accounting practice for intangible assets, this implies the need for a life cycle classification methodology that can capture the relative mix between growth opportunities and assets-in-place. This can be achieved by utilising multiple financial-based life cycle proxies. Therefore, the life cycle classification procedure employed in this study is based on [23] with some modifications to take into account the requirements and scope of this study. Based on previous studies (for example, [24], [25]), three proxy variables are selected to be used for the firm life cycle stage 
classification: market-to-book value of assets (MBA) ratio, capital expenditures to property, plant and equipment (CE) ratio and percentage of sales growth (SG). Besides being the most commonly used proxies for firm life cycle, two of the variables also represent one of the economic characteristics of firms important to this study, which is the proportion of assets-in-place relative to growth opportunities in representing firm value. The chosen proxy variables also reflect organizational change and sales generating ability and, therefore, are expected to signal differences in firms' strategic emphases. Overall, these life cycle classification proxies conform to [26]'s observations of a firm life cycle stage construct being a multi-dimensional phenomenon. Based on prior studies and the information obtained from Bursa Malaysia, these three life cycle proxies are computed for each firm in each year between 2002 and 2011.

Reference [23] classifies sample firms into life cycle stages by ranking them on each of the life cycle variables among all firms in the year irrespective of industry. By pooling over the entire cross-section of firms, the study implicitly assumes a homogeneous, economy-wide benchmark. However, it is known that industries, like individual firms, have unique operating structures that cause financial ratios to cluster by industry groupings. This indicates that ranking firms using this approach can potentially result in misclassification. As a result, the use of industry quintiles in assigning the scores for each firm on individual life cycle proxies will better capture firms' economic characteristics and strategic emphases within the industry and, consequently, improve the life cycle classification procedure. Scores are assigned for individual life cycle proxies in each year to allow for temporal shifts in the life cycle stage of sample firms. The life cycle proxies are given a score as illustrated in Table I.

TABLE I: SCORES ASSIGNED TO FIRM LIFE CYCLE PROXIES

\begin{tabular}{llll}
\hline \hline Industry Quintiles & MBA & CE & SG \\
\hline $0 \%-20 \%$ & 5 & 5 & 5 \\
$21 \%-40 \%$ & 4 & 4 & 4 \\
$41 \%-60 \%$ & 3 & 3 & 3 \\
$61 \%-80 \%$ & 2 & 2 & 2 \\
$81 \%-100 \%$ & 1 & 1 & 1 \\
\hline \hline
\end{tabular}

where: $1=$ Growth; 2 = Growth/Mature; 3 = Mature; 4 = Mature/Decline; and $5=$ Decline

The composite scores for each firm are obtained by summing the individual scores of life cycle proxy variables in each year. The range of the composite score depends on the number of variables used for life cycle classification. Therefore, with three variables, the composite score in this study ranges from three to fifteen. Note that sample firms in this study are to be classified into three main life cycle stages which are growth, mature and decline. This study will initially follow the method applied in [23], [27] in which sample firms are ranked on their composite scores and divided into five life cycle groups; growth, growth/mature, mature, mature/decline and decline. The life cycle stage classification is illustrated in Table II. Next, firms classified in the intermediate categories; growth/mature and mature/decline are deleted in order to increase the homogeneity among life cycle categories. Consequently, only three main life cycle groups will be retained for further tests.

TABLE II: FIRM LIFE CYCLE ClASSIFICATION BASED ON THE COMPOSITE SCORE

\begin{tabular}{lc}
\hline \hline Firm Life Cycle Stage & Composite Score \\
\hline Growth & $3-6$ \\
Growth/Mature & 7 \\
Mature & $8-11$ \\
Mature/Decline & 12 \\
Decline & $13-15$ \\
\hline \hline
\end{tabular}

\section{Value Relevance Tests}

In order to examine empirically the hypotheses, the valuation framework introduced by [11] is utilised in this study. Drawing upon previous studies on the value relevance of intangible assets, $\mathrm{H} 1$ predicts that intangible assets capitalised by firms in the pre-IFRS period do provide value-relevant information. Equation (1) is used to test $\mathrm{H} 1$ and can be expressed as:

$$
\mathrm{MV}_{i t}=\alpha_{0}+\alpha_{1} \mathrm{ADJ} \_\mathrm{BV} V_{i t}+\alpha_{2} \mathrm{IIA}_{i t}+\alpha_{3} \mathrm{NI}_{i t}+\varepsilon_{i t}
$$

Meanwhile, Equation (2) is used to test $\mathrm{H} 2 \mathrm{a}$ and $\mathrm{H} 2 \mathrm{~b}$ and can be expressed as follows:

$$
\begin{aligned}
& \mathrm{MV}_{i t}=\alpha_{0}+\alpha_{1} \mathrm{ADJ}_{-} \mathrm{BV}_{i t}+\alpha_{2} \mathrm{IIA}_{i t}+\alpha_{3} \mathrm{NI}_{i t}+\alpha_{4} \mathrm{G}_{i t}+\alpha_{5} \mathrm{D}_{i t}+ \\
& \alpha_{6}\left(\mathrm{G}_{i t} \times \mathrm{IIA}_{i t}\right)+\alpha_{7}\left(\mathrm{D}_{i t} \times \mathrm{IIA}_{i t}\right)+\varepsilon_{i t}
\end{aligned}
$$

$\mathrm{H} 3, \mathrm{H} 4 a$ and $\mathrm{H} 4 b$ are concerned mainly with the effect of IFRS adoption on firms that chose to capitalise intangible assets in the pre-IFRS period and are tested using Equations (3) and (4):

$$
\begin{aligned}
& \mathrm{MV}_{i t}=\alpha_{0}+\alpha_{1} \mathrm{ADJ}_{-} \mathrm{BV}_{i t}+\alpha_{2} \mathrm{IIA}_{i t}+\alpha_{3} \mathrm{NI}_{\mathrm{it}}+\alpha_{4} \mathrm{PRE}_{i t}+ \\
& \alpha_{5}\left(\mathrm{PRE}_{i t} \times \mathrm{IIA}_{i t}\right)+\varepsilon_{i t} \\
& \mathrm{MV}_{i t}=\alpha_{0}+\alpha_{1} \mathrm{ADJ}_{1} \mathrm{BV}_{i t}+\alpha_{2} \mathrm{IIA}_{i t}+\alpha_{3} \mathrm{NI}_{i t}+\alpha_{4} \mathrm{PRE}_{i t}+\alpha_{5} \mathrm{G}_{i t}+ \\
& \alpha_{6} \mathrm{D}_{i t}+\alpha_{7}\left(\mathrm{PRE}_{i t} \times \mathrm{IIA}_{i t}\right)+\alpha_{8}\left(\mathrm{PRE}_{i t} \times \mathrm{G}_{i t}\right)+\alpha_{9}\left(\mathrm{PRE}_{i t} \times \mathrm{D}_{i t}\right)+ \\
& \alpha_{10}\left(\mathrm{D}_{i t} \times \mathrm{IIA}_{i t}\right)+\alpha_{11}\left(\mathrm{D}_{i t} \times \mathrm{IIA}_{\mathrm{it}}\right)+\alpha_{12}\left(\mathrm{PRE}_{i t} \times \mathrm{G}_{i t} \times \mathrm{IIA}_{i t}\right)+ \\
& \alpha_{13}\left(\mathrm{PRE}_{i t} \times \mathrm{D}_{i t} \times \mathrm{IIA}_{i t}\right)+\varepsilon_{i t}
\end{aligned}
$$

where: $\mathrm{MV}_{i t}=$ market value of equity of firm $i 90$ days after the end of financial year $t$; $\mathrm{ADJ} \_\mathrm{BV}_{i t}=$ book value of equity of firm $i$ at the end of financial year $t$ less IIA $_{i t}$;IA IA $_{i t}=$ identifiable intangible assets of firm $i$ at the end of financial year $t ; \mathrm{NI}_{i t}=$ net operating income of firm $i$ at the end of financial year $t ; \mathrm{G}_{i t}=$ a dummy variable equal to 1 for firms in the Growth stage of firm life cycle, and 0 otherwise for firm $i$ at the end of financial year $t ; \mathrm{D}_{i t}=$ a dummy variable equal to 1 for firms in the Decline stage of firm life cycle, and 0 otherwise for firm $i$ at the end of financial year $t ; \mathrm{PRE}_{i t}=a$ dummy variable equal to 1 for firms in the pre-IFRS period, and 0 otherwise for firm $i$ at the end of financial year $t ; \varepsilon_{i t}=$ error term.

\section{E. Sample and Data}

The sample used in this study includes all Bursa Malaysia 
public-listed firms in the year 2002 to 2005 for the pre-IFRS period and the year 2008 to 2011 for the post-IFRS period. This study does not cover the periods 2006 and 2007 to allow for the transitional effect of IFRS implementation on the reporting of intangible assets. Firms that are included in the sample are those in the intangible-intensive industry identified in previous studies (see for example [28]-[30]). The industry sectors considered in this study include Industrial Products, Consumer Products, Trading/Services and Technology. Using this initial sample, the firm life cycle classification procedure described earlier is conducted to classify sample firms into the three stages of Growth, Mature and Decline. In order to test the hypotheses in this study, sample firms also need to be categorised into capitalisers and non-capitalisers in both the pre- and post-IFRS periods.

Consistent with the definition of intangible assets used in this study, the accounting treatment for identifiable intangible assets is used to perform this classification. Data needed to conduct the analyses in this study, are obtained from Bursa Malaysia Knowledge Centre database. Firms are only included in the final sample if all required data are available. This procedure yields a final sample of 4,331 firms-years, with 2,042 firm-years in the pre-IFRS period and 2,289 firm-years in the post-IFRS period. Overall, the sample selection process indicates that $60.4 \%$ of the total population within the period studied can be classified as capitalisers.

\section{RESULTS}

\section{A. Value Relevance of Intangible Assets in the Pre-IFRS Period}

Preliminary analysis indicates that MV is correlated with only two variables of interest (IIA and $\mathrm{G}^{*}$ IIA) in the expected direction (results not tabulated), suggesting that there is an association between these variables. However, there is no correlation between MV and D*IIA. Panel A of Table III presents the regression results based on Equation 1. It can be seen that, consistent with the expectation in $\mathrm{H} 1$, the coefficient on IIA is significant and positive at the 1 percent level $\left(\alpha_{2}=0.206, t\right.$-statistic $\left.=10.364\right)$. This finding indicates that the capitalisation of IIA is value relevant and thus provides support for $\mathrm{H} 1$.

$\mathrm{H} 2 \mathrm{a}$ and $\mathrm{H} 2 \mathrm{~b}$ are examined by utilising Equation 2 and the results are presented in Panel B of Table III. The interaction term G*IIA is included in the model and captures the difference in value relevance of IIA between Growth and Mature firms. Specifically, it is hypothesised that Growth firms will have higher value relevance of IIA than Mature firms during the pre-IFRS period.

The result shows that the coefficient on G*IIA is in the expected direction to that predicted in the hypothesis $\left(\alpha_{6}=\right.$ $0.096, t$-statistic $=3.547)$ and is also significant, indicating support for $\mathrm{H} 2 a$. This suggests that during the pre-IFRS period, the Malaysian market perceive the value relevance of IIA capitalised by Growth firms to be different that is higher than those capitalised by mature firms. Meanwhile, the interaction term D*IIA represents the difference in value relevance of IIA between Decline and Mature firms. H2b predicts that the value relevance of IIA for Decline firms will be lower than Mature firms. The findings presented in Panel B provide no support for $\mathrm{H} 2 \mathrm{~b}$ as it can be seen that the coefficient for D*IIA is positive and not significant $\left(\alpha_{7}=\right.$ $0.033, t$-statistic $=0.268$ ).

TABLE III: ThE TESTS OF VALUE RELEVANCE OF INTANGIBLE ASSETS IN THE PRE-IFRS PERIOD

\begin{tabular}{|c|c|c|c|c|}
\hline \multirow[t]{2}{*}{ Variables } & \multicolumn{2}{|c|}{$\begin{array}{c}\text { Panel A } \\
\text { H1 }\end{array}$} & \multicolumn{2}{|c|}{$\begin{array}{c}\text { Panel B } \\
\mathrm{H} 2 \mathrm{a} \text { and } \mathrm{H} 2 \mathrm{~b}\end{array}$} \\
\hline & Coefficient & $t$-statistic & Coefficient & $t$-statistic \\
\hline Intercept & 0.981 & $28.131 * * *$ & 0.947 & $\begin{array}{l}24.873^{* *} \\
*\end{array}$ \\
\hline ADJ_BV & 0.245 & $11.845 * * *$ & 0.275 & $\begin{array}{l}14.668 * * \\
*\end{array}$ \\
\hline IIA & 0.206 & $10.364 * * *$ & 0.205 & $9.677 * * *$ \\
\hline NI & 0.386 & $19.517 * * *$ & 0.283 & $\begin{array}{l}14.681 * * \\
*\end{array}$ \\
\hline G & & & 0.086 & $1.629 *$ \\
\hline $\mathrm{D}$ & & & -.174 & -.791 \\
\hline$G^{*} \boldsymbol{I I A}$ & & & 0.096 & $3.547 * * *$ \\
\hline$D * I I A$ & & & 0.033 & 0.268 \\
\hline $\mathrm{N}$ & 2042 & & 2042 & \\
\hline Adj. $R^{2}$ & 0.761 & & 0.806 & \\
\hline F-statistic & $914.262^{* * * *}$ & & $513.743^{* * * *}$ & \\
\hline
\end{tabular}

***Significant at the $1 \%$ level (one-tailed test when the sign is predicted; two-tailed otherwise); **Significant at the $5 \%$ level (one-tailed test when the sign is predicted; two-tailed otherwise); *Significant at the $10 \%$ level (one-tailed test when the sign is predicted; two-tailed otherwise); MV = Market value of equity 90 days after the end of financial year; ADJ_BV = Book value of equity (adjusted for reported net identifiable intangible assets); IIA = Identifiable intangible assets reported for the year; $\mathrm{AE}=$ Abnormal earnings; $\mathrm{G}=$ A dummy variable that is coded 1 for Growth firms and 0 otherwise; $\mathrm{D}=\mathrm{A}$ dummy variable that is coded 1 for Decline firms and 0 otherwise.

In summary, the results indicate that the IIA capitalised by these sample firms during the pre-IFRS are perceived by the market to be value relevant (H1 is supported). However, when extending the analysis across firm life cycle stages, the findings suggest that although there is a significant difference in the value relevance of IIA between Growth and Mature firms ( $\mathrm{H} 2 a$ is supported), the same evidence is not present between Mature and Decline firms (H2b is not supported). In other words, the market value IIA for Growth firms differently from IIA for Mature firms, but not between Mature and Decline firms.

\section{B. Comparison of the Pre-and Post-IFRS Periods}

Preliminary analysis based on Pearson correlations (results not tabulated) are consistent with the predicted positive associations between MV and PRE*IIA and MV and PRE*IIA*G and negative association between $M V$ and PRE*IIA*D. The highest correlations between the independent variables are between the interaction terms which are $\mathrm{G}$ and G*IIA (0.913), D and D*IIA (0.909), PRE*G and PRE*IIA*G (0.926) and PRE*D and PRE*IIA*D (0.880). There is no substantially high correlation between other independent variables, suggesting that multicollinearity might not be a problem in the regression models. The test of $\mathrm{H} 3$ is based on Equation 3 and the regression results are presented in Panel A of Table IV.

$\mathrm{H} 3$ posits that the coefficient on PRE*IIA will be positive and significant. However, the result shows that although the

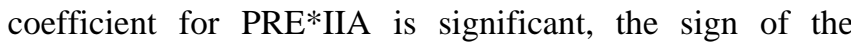
coefficient is in the opposite direction from what is predicted in H3 $\left(\alpha_{5}=-.123, t\right.$-statistic $\left.=-6.456\right)$. This indicates that the 
value relevance of IIA in the post-IFRS period is actually higher than the pre-IFRS period and, hence, provides no support for $\mathrm{H} 3$. Meanwhile, it is predicted in $\mathrm{H} 4 \mathrm{a}$ and $\mathrm{H} 4 \mathrm{~b}$ that the effect of the change in the value relevance of intangible assets between the pre- and post-IFRS periods is different across firm life cycle stages. The findings are provided in Panel B of Table IV.

TABLE IV: The TESTS of VALUE RELEVANCE OF INTANGIBLE AsSETS: A COMPARISON OF THE PRE-AND POST-IFRS PERIODS

\begin{tabular}{|c|c|c|c|c|}
\hline \multirow[t]{2}{*}{ Variables } & \multicolumn{2}{|c|}{$\begin{array}{c}\text { Panel A } \\
\text { H3 }\end{array}$} & \multicolumn{2}{|c|}{$\begin{array}{c}\text { Panel B } \\
\mathrm{H} 4 \mathrm{a} \text { and } \mathrm{H} 4 \mathrm{~b}\end{array}$} \\
\hline & Coefficient & $t$-statistic & Coefficient & $t$-statistic \\
\hline Intercept & 0.602 & $22.799 * * *$ & 0.643 & $21.879 * * *$ \\
\hline ADJ_BV & 0.304 & $22.205^{* * *} *$ & 0.339 & $26.969 * * *$ \\
\hline IIA & 0.294 & $19.694 * * *$ & 0.254 & $15.573 * * *$ \\
\hline NI & 0.393 & $29.673 * * *$ & 0.286 & $21.992 * * *$ \\
\hline PRE & 0.333 & $9.094 * * *$ & 0.251 & $5.888 * * *$ \\
\hline$P R E^{*} I I A$ & -0.123 & $-6.456 * * *$ & -0.083 & $-3.572 * * *$ \\
\hline G & & & 0.010 & 0.221 \\
\hline $\mathrm{D}$ & & & -0.099 & -0.838 \\
\hline PRE*G & & & 0.077 & 1.066 \\
\hline PRE*D & & & -0.051 & -0.197 \\
\hline G*IIA & & & 0.126 & $5.677 * * *$ \\
\hline D*IIA & & & -.027 & -0.376 \\
\hline$P R E^{*} G^{*} I I A$ & & & -0.034 & -0.940 \\
\hline$P R E^{*} D^{*} I I A$ & & & 0.048 & 0.322 \\
\hline $\mathrm{N}$ & 2289 & & 2289 & \\
\hline Adj. $\mathrm{R}^{2}$ & 0.815 & & 0.849 & \\
\hline F-statistic & $1868.554 * * *$ & & $912.815 * * *$ & \\
\hline
\end{tabular}

***Significant at the $1 \%$ level (one-tailed test when the sign is predicted; two-tailed otherwise); **Significant at the $5 \%$ level (one-tailed test when the sign is predicted; two-tailed otherwise); *Significant at the $10 \%$ level (one-tailed test when the sign is predicted; two-tailed otherwise); MV = Market value of equity 90 days after the end of financial year; ADJ_BV = Book value of equity (adjusted for reported net identifiable intangible assets); IIA = Identifiable intangible assets reported for the year; $\mathrm{AE}=$ Abnormal earnings; $\mathrm{G}=\mathrm{A}$ dummy variable that is coded 1 for Growth firms and 0 otherwise; $\mathrm{D}=\mathrm{A}$ dummy variable that is coded 1 for Decline firms and 0 otherwise; PRE = A dummy variable that is coded 1 for Pre-IFRS period and 0 otherwise.

In general, the findings do not support either $\mathrm{H} 4 \mathrm{a}$ or $\mathrm{H} 4 \mathrm{~b}$. Specifically, it is expected that the coefficient on the interaction term PRE*IIA*G that captures the effect of the change in value relevance of intangible assets for Growth and Mature firms will exhibit a significant positive sign in order to be consistent with $\mathrm{H} 4 \mathrm{a}$. The coefficient on the interaction term PRE*IIA*D captures the effect of the change in value relevance for Decline and Mature firms and is hypothesised to show a negative significant sign to provide support for H4b. However, as can be seen in Panel B of Table 4 , none of the coefficients is significant suggesting that there is no evidence to support either $\mathrm{H} 4 \mathrm{a}$ or $\mathrm{H} 4 \mathrm{~b}$. Specifically, the coefficient on PRE*IIA*G is found to be in the opposite direction from the expectation in $\mathrm{H} 4 \mathrm{a}$, suggesting that Mature firms might have greater relevance of IIA than Growth firms. This result, however is not supported due to the insignificant coefficient $\left(\alpha_{12}=-.034, t\right.$-statistic $\left.=-.940\right)$. Similarly, the coefficient on PRE*IIA*D also does not have the predicted negative sign and it is also insignificant, and thus providing no support for $\mathrm{H} 4 \mathrm{~b}\left(\alpha_{13}=0.048, t\right.$-statistic $\left.=0.322\right)$.

Overall, the findings indicate that the Malaysian market attaches higher value relevance for IIA after the introduction of the new standard for intangible assets (H3 is not supported). The findings also provide evidence that the effect of the change in the value relevance of IIA between the preand post-IFRS period does not apply across firm life cycle stages in which no difference is evident between Growth, Mature and Decline firms (H4a and $\mathrm{H} 4 \mathrm{~b}$ are not supported).

\section{CONCLUSIONS}

Based on the findings, it appears that the restrictions in accounting for intangible assets do not remove or reduce the ability of the managers of Growth and Mature firms to communicate credible signals on intangible asset quality. As a matter of fact, it can be argued that the adoption of IFRS improves the credibility of the signalling mechanism used by these firms, most likely through the increase in the reliability of amounts reported for intangible assets. Meanwhile, for Decline firms, it can be seen that in the pre-IFRS period, there is a tendency for them to use the accounting choice of capitalisation to behave opportunistically instead of signalling value to the investors. However, in the post-IFRS period, the discretion allowed for managers to recognise intangible assets has been largely reduced. This, in a way, has restricted the potential occurrence of managerial opportunistic behavior among Decline firms, leading to reduced investors' confidence in the reliability of intangible assets amounts recognised by these firms. Consequently, in the post-IFRS period, the market discounts the value of intangible assets reported by Decline firms when compared to other firms.

\section{ACKNOWLEDGMENT}

The authors would like to fully acknowledge the financial support provided by Universiti Pendidikan Sultan Idris in conducting the research.

\section{REFERENCES}

[1] T. Abrahams and B. K. Sidhu, "The role of R\&D capitalisation in firm valuation and performance measurement," Australian Journal of Management, vol. 23, pp. 169-183, 1998.

[2] T. D. Fields, T. Z. Lys, and L. Vincent, "Empirical research on accounting choice," Journal of Accounting and Economics, vol. 31, pp. 255-307, 2001.

[3] J. Godfrey and P. S. Koh, "The relevance to firm valuation of capitalising intangible assets in total and by category," Australian Accounting Review, vol. 11, pp. 39-48, 2001.

[4] A. S. Zaleha, I. Muhd-Kamil, K. Jagjit, and M. N. Hamezah, "The value relevance of intangibles non-current assets in different economic conditions and accounting environments," Malaysian Accounting Review, vol. 8, pp. 43-66, 2009.

[5] N. Karampinis and D. Hevas, "The effect of the mandatory application of IFRS on the value relevance of accounting data: Some evidence from Greece," European Research Studies, vol. 12, pp. 73-100, 2009.

[6] G. Iatridis, and S. Rouvolis, "The post-adoption effects of the implementation of International Financial Reporting Standards in Greece," Journal of International Accounting, Auditing \& Taxation, vol. 19, pp. 55-65, 2010.

[7] D. Cormier, S. Demaria, P. Lapointe-Antunes, and R. Teller, "First-time adoption of IFRS, managerial incentives, and value-relevance: Some French evidence," Journal of International Accounting Research, vol. 8, pp. 1-22, 2009.

[8] D. W. Taylor, "Costs-benefits adoption of IFRSs in countries with different harmonization histories," Asian Review of Accounting, vol. 17, pp. 40-58, 2009.

[9] K. Mohd Halim, A. A. Rozainun, and I. Muhd-Kamil, "Value relevance of book value and earnings: Evidence from two different financial reporting regimes," Journal of Financial Reporting and Accounting, vol. 7, pp. 1-16, 2009. 
[10] S. Morricone, R. Oriani, and M. Sobrero. (2009). The value relevance of intangible assets and the mandatory adoption of IFRS. [Online] Available:

http://papers.ssrn.com/sol3/papers.cfm?abstract_id=1600725,

http://www.google.com.au/url?sa=t\&source=web\&cd=14\&ved=0CC 8 QFjADOAo\&url=http://papers.ssrn.com/sol3/Delivery.cfm/SSRN_ID 1600725_code1479026.pdf\%3Fabstractid\%3D1600725\%26mirid\%3 D1\&rct=j\&q=value \%20relevance\%20intangible\%20assets\%20ifrs\&e $\mathrm{i}=\mathrm{NBESTfmJH} 4$ QCzZnTsMgI\&usg=AFQjCNHpMfoaDF1FiwuCEiS z_cIbFdJr_Q.

[11] J. A. Ohlson, "Earnings, book values, and dividends in equity valuation," Contemporary Accounting Research, vol. 11, pp. 661-687, 1995.

[12] L. Oliveira, L. L. Rodrigues, and R. Craig, "Intangible assets and value relevance: Evidence from the Portuguese Stock Exchange," The British Accounting Review, vol. 42, pp. 241-252, 2010.

[13] K. Chalmers, G. Clinch, and J. Godfrey, "Adoption of International Financial Reporting Standards: Impact on the value relevance of intangible assets," Australian Accounting Review, vol. 18, pp. 237-247, 2008.

[14] R. W. Holthausen, "Accounting method choice: Opportunistic behavior, efficient contracting, and information perspectives," Journal of Accounting and Economics, vol. 12, pp. 207-218, 1990.

[15] R. W. Holthausen and R. Leftwich, "The economic consequences of accounting choice: implications of costly contracting and monitoring," Journal of Accounting and Economics, vol. 5, pp. 77-117, 1983.

[16] M. H. Miller and F. Modigliani, "Dividend policy, growth, and the valuation of shares," The Journal of Business, vol. 34, pp. 411-433, 1961.

[17] S. C. Myers, "Determinants of corporate borrowing," Journal of Financial Economics, vol. 5, pp. 147-175, 1977.

[18] E. L. Black, "Life-cycle impacts on the incremental value-relevance of earnings and cash flow measures," Journal of Financial Statement Analysis, vol. 4, pp. 40-56, 1998.

[19] D. S. Dhaliwal, W. G. Heninger, and K. E. I. Hughes, "The investment opportunity set and capitalization versus expensing methods of accounting choice," Accounting and Finance, vol. 39, pp. 151-175, 1999.

[20] W. C. Kester, "Today's options for tomorrow's growth," Harvard Business Review, vol. 62, pp. 153-160, 1984.

[21] M. A. Abernethy, A. Wyatt, P. Bianchi, S. Labory, S. Zambon, A. Del Bello, and B. Lev. (2003). Study on the measurement of intangible assets and associated reporting practices. [Online]. Available: http://ec.europa.eu/internal_market/services/docs/brs/competitiveness/ 2003-study-intangassets-full_en.pdf

[22] S. Sudarsanam, G. Sorwar, and B. Marr, "Real options and the impact of intellectual capital on corporate value," Journal of Intellectual Capital, vol. 7, pp. 291-308, 2006.

[23] J. H. Anthony and K. Ramesh, "Association between accounting performance measures and stock prices: A test of the life cycle hypothesis," Journal of Accounting and Economics, vol. 15, pp. 203-227, 1992.

[24] S. Kallapur and M. A. Trombley, "The association between investment opportunity set proxies and realized growth," Journal of Business Finance \& Accounting, vol. 26, pp. 505-519, 1999.

[25] T. Adam and V. K. Goyal, "The investment opportunity set and its proxy variables," The Journal of Financial Research, vol. 31, pp. 41-63, 2008

[26] S. H. Hanks, C. J. Watson, E. Jansen, and G. N. Chandler, "Tightening the life cycle construct: A taxonomic study of growth stage configurations in high technology organizations," Entrepreneurship Theory and Practice, vol. 18, pp. 5-30, 1993.

[27] D. S. Jenkins, G. D. Kane, and U. Velury, "The impact of the corporate life-cycle on the value-relevance of disaggregated earnings components," Review of Accounting \& Finance, vol. 3, pp. 5-20, 2004

[28] A. Wyatt, "Accounting recognition of intangible assets: Theory and evidence on economic determinants," The Accounting Review, vol. 80, pp. 967-1000, 2005.

[29] A. Ritter and P. Wells, "Identifiable intangible asset disclosures, stock prices and future earnings," Accounting and Finance, vol. 46, pp. 843-863, 2006.

[30] K. Chalmers and J. Godfrey, "Intangible assets: Diversity of practices and potential impacts from AIFRS adoption," Australian Accounting Review, vol. 16, pp. 60-71, 2006.

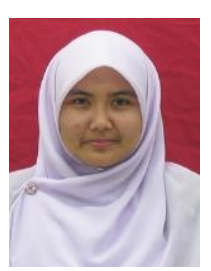

Hartini Jaafar holds a doctorate degree from the University of Tasmania, Australia in the field of Financial Reporting. She previously lectured at the Department of Accounting and Finance, College of Business Management, Universiti Tenaga Nasional, Malaysia for two years.

Dr. Hartini is currently a senior lecturer at the Department of Accounting and Finance, Faculty of Management and Economics, Universiti Pendidikan Sultan Idris, Malaysia Her field of interest includes financial reporting, corporate governance and accounting education.

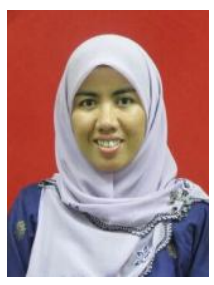

Hazianti Abdul Halim is awarded with a Ph.D. in Accounting by the University of Tasmania, Australia. She previously worked as an auditor for two years before pursuing her academic career as a tutor at the Department of Accounting and Finance, Faculty of Management and Economics, Universiti Pendidikan Sultan Idris, Malaysia.

Dr. Hazianti is now a senior lecturer at the same reporting, financial planning and taxation. 